\title{
Lymphangioma circumscriptum of the vulva
}

\author{
Pairoj Chattranukulchai, Sudarat Satitthummanid, Sarinya Puwanant, \\ Smonporn Boonyaratavej
}

Department of Medicine, King Chulalongkorn Memorial Hospital, Chulalongkorn University, Bangkok, Thailand

\section{Correspondence to} Dr Pairoj Chattranukulchai, pairoj.md@gmail.com
To cite: Chattranukulchai $P$, Satitthummanid $S$

Puwanant $S$, et al. BMJ Case Rep Published online: [please include Day Month Year] doi:10.1136/bcr-2013009297

\section{DESCRIPTION}

A 24-year-old woman presented with odourless, chronic progressive vulvar lesions since she was a teenager. The lesion shows multiple erythematous clusters of translucent vesicles of varying sizes that resemble frog spawn (figure 1A). She has also been diagnosed as having congenital lymphoedema of the lower legs (figure 1B).

Histopathology revealed large, irregular cystic dilatation of lymphatic channels which contained proteinaceous fluid and red cells in the upper dermis and lift up against the covering epidermis consistent with lymphangioma circumscriptum (microcystic lymphatic malformation, figure $1 \mathrm{C}$ ), a common form of cutaneous lymphangioma the typical locations of which are the proximal extremities, axilla and the oral cavity. Vulvar involvement like in this case is uncommon. Its vesicles can be colourless or vary from pink to dark red because of internal haemorrhage. This change makes it resemble other lesions, such as vulvar herpes zoster or Kaposi's sarcoma. ${ }^{1-3}$ Moreover, it can be associated with congenital lymphoedema in other parts of the body and can link to some rare genetic syndromes. ${ }^{3}$ In this patient there

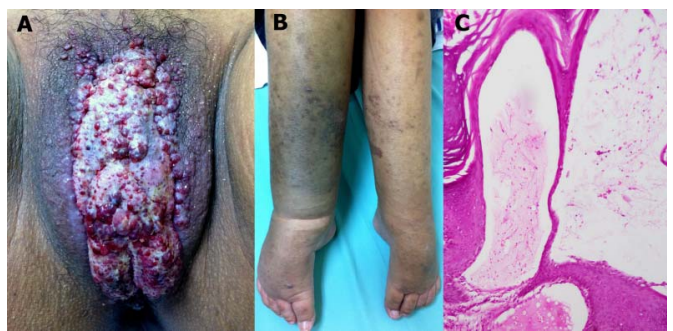

Figure 1 (A) Multiple erythematous clusters of translucent vesicles of varying sizes that resemble frog spawn at vulva. (B) Congenital lymphoedema of her lower legs. (C) Histopathology revealed large, irregular cystic dilatation of lymphatic channels in the dermis which contained proteinaceous fluid and red cells. were no signs of syndrome abnormalities along with no additional relevant history or family history of genetic diseases.

She was referred to an oedema therapist for the compression therapy of her legs; meanwhile the vesicular lesion has been left without excision because of a high recurrence rate owing to its rather deep component.

\section{Learning points}

- It is one of the common forms of cutaneous lymphangioma, typically showing multiple clusters of translucent vesicles with a variety of colours.

- Histopathology primarily shows intradermal cystic dilatation of lymphatic channels without connection with the systemic lymphatic channel.

- High recurrence rate after excision makes it difficult to treat.

Contributors All authors contributed in preparing and reviewing the manuscript. SP and SS contributed to additional history taking and reviewing the revision.

Competing interests None.

Patient consent Obtained.

Provenance and peer review Not commissioned; externally peer reviewed.

\section{REFERENCES}

1 Sultan A, Dadras SS, Bay JM, et al. Prox-1, podoplanin and HPV staining assists in identification of lymphangioma circumscriptum of the vulva and discrimination from vulvar warts. Histopathology 2011;59:1274-7.

2 Shah TN, Shekokar S, Venkatesh S. Lymphangioma circumscriptum of the vulva: a rare case report. Eur J Obstet Gynecol Reprod Biol 2012;165:131-2.

3 Terushkin V, Marmon S, Fischer $\mathrm{M}$, et al. Verrucous lymphangioma circumscriptum. Dermatol Online J 2012;18:9.

Copyright 2013 BMJ Publishing Group. All rights reserved. For permission to reuse any of this content visit http://group.bmi.com/group/rights-licensing/permissions.

BMJ Case Report Fellows may re-use this article for personal use and teaching without any further permission.

Become a Fellow of BMJ Case Reports today and you can:

- Submit as many cases as you like

- Enjoy fast sympathetic peer review and rapid publication of accepted articles

- Access all the published articles

- Re-use any of the published material for personal use and teaching without further permission

For information on Institutional Fellowships contact consortiasales@bmjgroup.com

Visit casereports.bmj.com for more articles like this and to become a Fellow 